\title{
Heterotopic mesenteric and omental ossification incidentally found in a patient with multiple abdominal surgical operations because of gunshot injury
}

\author{
๑ Süleyman Utku Çelik, M.D., ๑ Rahman Şenocak, M.D., ๑ Oğuz Hançerlioğulları, M.D.
}

Department of General Surgery, Gülhane Training and Research Hospital, Ankara-Turkey

\begin{abstract}
Heterotopic mesenteric and/or omental ossification is an uncommon bone-like lesion located inside the abdominal cavity. Its etiology is unclear, but most of the patients with this rare disease had a history of a blunt or penetrating abdominal trauma or multiple surgical operations owing to surgical complications. Heterotopic mesenteric and/or omental ossification may be asymptomatic or may present with symptoms of bowel obstruction or cause a severe complication, such as bowel perforation. Due to its rarity, intra-abdominal ossification may sometimes be overlooked or misdiagnosed. However, the surgeon should be aware of this unusual condition, particularly in patients with a previous surgical history. In this study, we present a case of heterotopic mesenteric and omental ossification incidentally found in a $4 \mathrm{I}$-year-old man with multiple abdominal surgical operations because of a gunshot injury.
\end{abstract}

Keywords: Abdominal injuries; heterotopic ossification; mesentery; omentum.

\section{INTRODUCTION}

Heterotopic ossification describes bone formation at an abnormal anatomic location, usually in non-skeletal soft tissues because of a systemic or inflammatory condition. ${ }^{[l]}$ This benign reactive process of mature bone formation occurs in response to a variety of clinical settings, including neurogenic, genetic, posttraumatic, and postsurgical. ${ }^{[2]}$ Heterotopic mesenteric and/or omental ossification is an uncommon bone-like lesion located inside the abdominal cavity that arises from trauma, intra-abdominal infection, or surgery. ${ }^{[1,3,4]}$ Heterotopic bone-like formation is generally found not only in the mesentery but also in the mesoappendix, omentum, peritoneal surfaces, or laparotomy scars. ${ }^{[3,5,6]}$ Due to its rarity, the data are limited to case studies, and the true incidence of this reactive process remains unclear. ${ }^{[6]}$ In clinical settings, patients with mesenteric or omental ossification can be asymptomatic or may present with chronic abdominal pain, discomfort, or intestinal obstruction. ${ }^{[7]}$ We herein report a rare case of heterotopic mesenteric and omental ossification incidentally found in a $4 \mathrm{I}$-year-old male patient with multiple abdominal surgical operations because of a gunshot injury.

\section{CASE REPORT}

A 4I-year-old man who underwent multiple abdominal surgical operations after gunshot injury was admitted to our clinic for ileostomy closure. The patient had no other significant past medical history and no family history. His surgical history was notable for emergency right nephrectomy, right hemicolectomy with end ileostomy, and applications of intra-abdominal vacuum-assisted closure therapy 15 months before admission. Physical examination was unremarkable except for a large incisional hernia following midline laparotomy and ileostomy. Laboratory studies were also unremarkable.

Preoperative computed tomography (CT) scan of the abdomen/pelvis revealed multiple linear branching radiopaque

Cite this article as: Çelik SU, Şenocak R, Hançerlioğulları O. Heterotopic mesenteric and omental ossification incidentally found in a patient with multiple abdominal surgical operations because of gunshot injury. Ulus Travma Acil Cerrahi Derg 2019;25:531-534.

Address for correspondence: Süleyman Utku Çelik, M.D.

Gülhane Eğitim ve Araştırma Hastanesi, Genel Cerrahi Kliniği, Etlik, 06010 Ankara, Turkey

Tel: +90 312 - 3042000 E-mail: s.utkucelik@hotmail.com

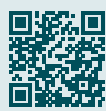

Ulus Travma Acil Cerrahi Derg 2019;25(5):53I-534 DOI: 10.5505/tjtes.2018.440I4 Submitted: 22.10.2018 Accepted: 27.10.2018 Online: 29.10.2018

Copyright 2018 Turkish Association of Trauma and Emergency Surgery 

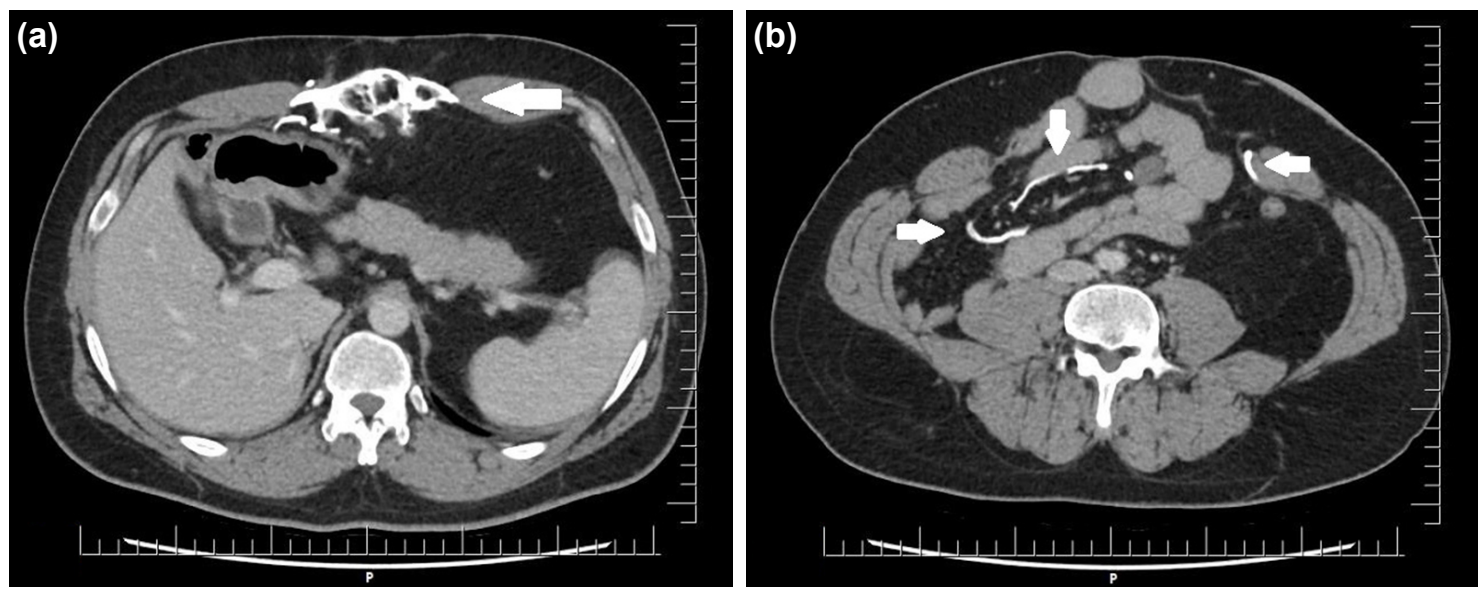

Figure 1. CT shows high-attenuation linear density and ossification within the omentum (a) and mesentery (b).

density and ossification within the mesentery and omentum, as well as a herniation of the intra-abdominal contents through an abdominal wall defect (Fig. I).

A midline laparotomy was required for the restoration of intestinal continuity and to close the end ileostomy. Extensive adhesions between adjacent bowel loops requiring adhesiolysis and several mesenteric, omental, and peritoneal sharp bone fragments were seen during the surgical procedure (Fig. 2). In addition, a long dagger-like bone fragment extending from the xiphisternal joint along the vertical midline abdom-

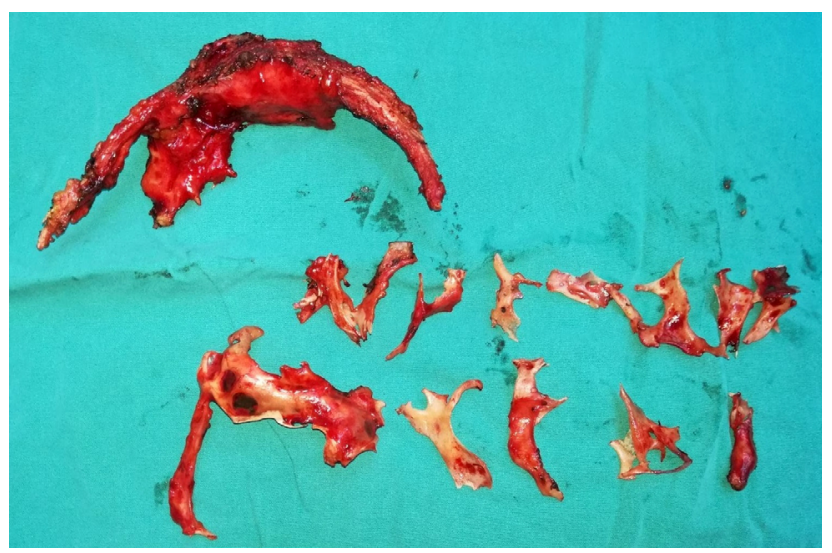

Figure 2. Ossified bone fragment encountered in the abdominal cavity. inal incision was released (Fig. 3). There was no evidence of intraluminal invasion related to these bone-like lesions. After removal of these sharp bone fragments from the abdominal wall, omentum, and small bowel mesentery; ileostomy was closed, and bowel continuity was restored. Finally, the ventral incisional hernia was repaired using a polypropylene mesh.

Pathological examination of the excised bone-like lesions revealed dense organized lamellar bone trabeculae in fibroadipose connective tissue. There was also no cellular atypia or evidence of malignancy. The clinical and pathological findings were compatible with heterotopic ossification. The patient had an uneventful recovery and was discharged on postoperative day 7 .

\section{DISCUSSION}

Heterotopic ossification, which is defined as the development of lamellar bone outside the skeletal system, is a rare condition. ${ }^{[1-3]}$ Intra-abdominal heterotopic bone formation is also extremely rare and specifically found in the mesentery, omentum, and peritoneum. In addition, this benign process may occur in abdominal incision sites. ${ }^{[1,5,8]}$ The etiology is unclear although it is thought to occur through an endochondral pathway without clear gene mutations causing hereditary conditions of heterotopic ossification. ${ }^{[1]}$ Some authors also hypothesized that bone fragments of the symphysis pubis or
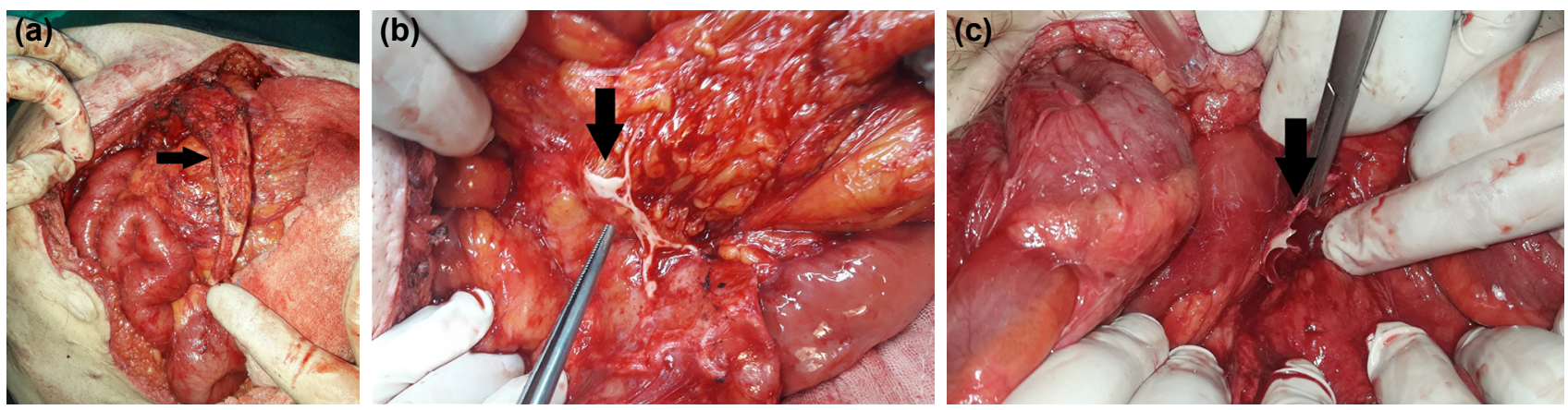

Figure 3. (a) Dagger-like bone fragment extending from the xiphisternal joint along the vertical midline abdominal incision; (b) heterotopic bone formation in the omentum; (c) heterotopic ossification in the mesentery. 
xiphoid are inoculated into the abdominal cavity or the incision site during the surgical intervention, and the seeding of periosteal or perichondrial cells leads to bone formation. [7,9,10] The time interval between predisposing factor and diagnosis may be as early as one month, which is contrary to the thought that the ossification occurs over the years. ${ }^{[10-12]}$ In this case, because heterotopic ossification was found incidentally and did not cause a complication, it was difficult to know the time interval between the first surgical operations and diagnosis. However, the bone-like structures were realized 15 months after the first surgical interventions.

To our knowledge, there are fewer than 50 cases of intraabdominal heterotopic ossification reported in the relevant literature. ${ }^{[3,4]}$ There is a striking male predominance (as high as 10:1) with an average age at diagnosis of 50 years. ${ }^{[3,6,10,13]}$ Patients afflicted with heterotopic mesenteric and/or omental ossification commonly present with nonspecific abdominal symptoms, or, as in this case, it may be incidentally found during a laparotomy. ${ }^{[4,6,10]}$ Bowel obstruction and intestinal perforation associated with bone-like lesions located inside the abdominal cavity were also presented in a few cases. ${ }^{[7,10,11]}$ An abdominal CT scan can be helpful in the diagnosis of intra-abdominal heterotopic ossification, but the preoperative diagnosis is usually quite difficult. ${ }^{[8,14]} \mathrm{On} C \mathrm{CT}$ scan, the lesions appear as multiple branching, and linear opacities with a welldefined cortex containing internal trabecular ossifications, and this finding is nearly always depicted as contrast extravasation from the bowel lumen. ${ }^{[3,15]}$ The differential diagnosis for heterotopic mesenteric ossifications includes dystrophic calcification, foreign material, calcified abdominal cysts, extraskeletal osteosarcoma, or other osseous malignancies. $[8,13,16]$ However, accurate diagnosis can only be achieved with a histopathological examination. ${ }^{[3]}$

Conservative management should be the initial strategy for treating heterotopic mesenteric ossification, especially in asymptomatic patients. In case of the failure of conservative treatment, a disease-related complication, or the possibility of a malignancy, a surgical approach is inevitable. ${ }^{[3,1,13]}$ Complete excision is recommended if feasible. However, it should be noted that intra-abdominal ossifications are benign bone-like lesions with no malignant potential, and aggressive resections may be significantly associated with increased morbidity and mortality. ${ }^{[4,17]}$ Although recurrence is relatively rare, some pharmacologic agents, including non-steroidal anti-inflammatory drugs, diphosphonates, cimetidine, or even prophylactic local radiotherapy, have been used to prevent recurrence following resection. ${ }^{[8,10,11,14,16]}$

In the present case, intra-abdominal heterotopic ossification was found incidentally during closure of the temporary ileostomy 15 months after the first surgical interventions. These bone-like fragments were most likely result of the multiple laparotomies, serial washouts and debridements, and applications of intra-abdominal vacuum-assisted closure ther- apy. In the literature, most of the patients afflicted heterotopic mesenteric ossification had a history of an abdominal trauma, such as gunshot wounds, stab injury, or high-speed motor vehicle collision, or multiple surgical operations, due to surgical complications. ${ }^{[3,4,8,14-17]}$ Interestingly, some patients had also a history of intra-abdominal vacuum-assisted closure therapy, as in this case. ${ }^{[3,8,10,11]}$

In conclusion, due to the rarity of these lesions, it is difficult to blame one factor as the cause of heterotopic mesenteric ossification. However, the surgeon should be aware of this unusual condition, particularly in patients with a previous surgical history. In clinical settings, it should not be forgotten that these bone-like lesions are benign with no malignant. Therefore, if it is difficult to resect all ossified tissue, partial excision should be considered not to cause a complication. Although this case report describes only one patient, there is a need for cumulative evidence for the clinical features and optimal management strategies for this unusual condition.

\section{Conflict of interest: None declared.}

\section{REFERENCES}

1. Amalfitano M, Fyfe B, Thomas SV, Egan KP, Xu M, Smith AG, et al. A case report of mesenteric heterotopic ossification: Histopathologic and genetic findings. Bone 2018;109:56-60. [CrossRef]

2. Garcia RA, Demicco EG, Klein MJ, Schiller AL. Bones, Joints and Soft Tissue. In: Strayer DS, editor. Rubin's Pathology: Clinicopathologic Foundations of Medicine. 7th ed. Philadelphia: Wolters Kluwer Health; 2015. p. 1305-80.

3. Torgersen Z, Osmolak A, Bikhchandani J, Forse AR. Ectopic bone in the abdominal cavity: a surgical nightmare. J Gastrointest Surg 2013;17:1708-11. [CrossRef]

4. Como JJ, Yowler CJ, Malangoni MA. Extensive heterotopic mesenteric ossification after penetrating abdominal trauma.J Trauma 2008;65:1567.

5. Reynoso J, Christensen D, Latifi R. Heterotopic mesenteric ossification as a cause of persistent enterocutaneous fistula: overview of the literature and addition of a new case. Eur Surg 2012;44:285-90. [CrossRef]

6. Hogan NM, Caffrey E, Curran S, Sheehan M, Joyce MR. Heterotopic ossification of the abdominal wall. Int J Surg Case Rep 2012;3:489-91.

7. Wang Y, Stanek A, Grushka J, Fata P, Beckett A, Khwaja K, et al. Incidence and factors associated with development of heterotopic ossificationafter damage control laparotomy.Injury 2018;49:51-5. [CrossRef]

8. Merrell JJ, Sadro CT, Chew FS. Heterotopic Mesenteric Ossification after Blunt Abdominal Trauma and Multiple Surgical Operations. Radiol Case Rep 2015;3:243. [CrossRef]

9. Obeid A, Sarhane K, Berjaoui T, Abiad F. Heterotopic intra-abdominal ossification in a complex ventral hernia defect. J Wound Care 2014;23:S5-9. [CrossRef]

10. Lao VV, Lao OB, Figueredo E. Postoperative Bowel Perforation due to Heterotopic Ossification (Myositis Ossificans Traumatica): A Case Report and Review of the Literature. Case Rep Gastrointest Med 2011;2011:908514. [CrossRef]

11. Hashash JG, Zakhary L, Aoun EG, Refaat M. Heterotopic mesenteric ossification. Colorectal Dis 2012;14:e29-30. [CrossRef]

12. Shi X, Zhang W, Nabieu PF, Zhao W, Fu C. Early postoperative heterotopic omental ossification: report of a case. Surg Today 2011;41:137-40.

13. Patel RM, Weiss SW, Folpe AL. Heterotopic mesenteric ossification: a distinctive pseudosarcoma commonly associated with intestinal obstruc- 
tion. Am J Surg Pathol 2006;30:119-22. [CrossRef]

14. Honjo H, Kumagai Y, Ishiguro T, Imaizumi H, Ono T, Suzuki O, et al. Heterotopic mesenteric ossification after a ruptured abdominal aortic aneurism: case report with a review of literatures. Int Surg 2014;99:47984. [CrossRef]

15. Hicks CW, Velopulos CG, Sacks JM. Mesenteric calcification following abdominal stab wound. Int J Surg Case Rep 2014;5:476-9. [CrossRef]

16. Baker JC, Menias CO, Bhalla S. Bone in the belly: traumatic heterotopic mesenteric ossification. Emerg Radiol 2012;19:429-36. [CrossRef]

17. Sapalidis K, Strati TM, Liavas L, Kotidis E, Koletsa T, Tsiompanou F, et al. Heterotopic mesenteric ossification of ileostomy - "intraabdominal myositis ossificans".Rom J Morphol Embryol 2016;57:277-81.

\section{OLGU SUNUMU - ÖZET}

\section{Ateşli silah yaralanması nedeniyle birden fazla abdominal cerrahi operasyon geçiren bir hastada rastlantısal olarak bulunan heterotopik mezenterik ve omental ossifikasyon \\ Dr. Süleyman Utku Çelik, Dr. Rahman Şenocak, Dr. Oğuz Hançerlioğulları}

Gülhane Eğitim ve Araştırma Hastanesi, Genel Cerrahi Kliniği, Ankara

Heterotopik mezenterik ve/veya omental ossifikasyon, karın boşluğunda görülen kemik benzeri bir lezyondur. Bu nadir rastlanan klinik tablonun etiyolojisi belirsizdir, ancak bu hastaların çoğunda künt veya penetran abdominal travma veya cerrahi komplikasyonlar nedeniyle çoklu cerrahi girişim öyküsü vardır. İntraabdominal heterotopik ossifikasyon semptomsuz olabileceği gibi bağırsak tıkanıklığı semptomlarına veya bağırsak perforasyonu gibi ciddi bir komplikasyona neden olabilir. Kemikleşme benzeri oluşumlar, nadir görülmesi nedeniyle, bazen gözden kaçabilmekte ya da yanlış teşhis edilerek intraabdominal malignite veya opak kaçağı ile karıştırılabilmektedir. Bu sebeple cerrahlar, bu olağandışı tabloyu özellikle daha önceden geçirilmiş bir abdominal cerrahi öyküsü olan hastalarda akıllarında bulundurmalıdır. Bu yazıda, ateşli silah yaralanması nedeniyle çok sayıda abdominal cerrahi işlem geçiren 4 I yaşında bir erkek hastada rastlantısal olarak karşılaşılan heterotopik mezenterik ve omental ossifikasyon olgusunu sunuyoruz.

Anahtar sözcükler: Heterotopik ossifikasyon; karın yaralanmaları; mezenter; omentum. 